\title{
Relief suitability for Ploiești - Pașcani fast road construction
}

\author{
Robert Dobre \\ Geomorphology - Pedology - Geomatics Department \\ Faculty of Geography, University of Bucharest \\ Bucharest, Romania
}

\begin{abstract}
Ploiești - Pașcani fast road one of the most important infrastructure project in Romania. Based on the economic and environmental indicators generated by the National Transport Model used in the General Master Plan for Transport (MPGT) in Romania, resulted that the project is a priority transportation of our country. The estimated length is $327.5 \mathrm{~km}$ and total value for the full implementation of the project is 1304.41 mil. euro without VAT. The implementation period will be five years (two years to achieve technical and economic documents, feasibility study and technical project and four years for work execution).
\end{abstract}

Keywords - fast road; technical solution; geomorphology; geomorphotechnique analysis

\section{INTRODUCTION}

Currently, the Ploiești, Buzău, Focșani, Bacău and Pașcani municipalities are connected by the DN2 national road and DJ208 county road, whose capacity is exceeded on several sectors where traffic speed is limited either by the conditions of relief.

\section{LOCATION OF THE ACTION}

Ploiești - Pașcani fast road is located approximately in the east of the country. The analysis was focused on the first critical sector, one of Ploiesti and Buzau, $65 \mathrm{~km}$ length. A detailed (geomorphological and geomorphotechnique) analysis is absolutely necessary because of the geological context and because of geomorphological peculiarities [1].

\section{SCOPE AND OBJECTIVES}

We were used detailed analysis made in the field in conjunction with GIS techniques analysis, in order to establish the required types of construction solutions needed in order to build the project (road junctions, bridges, culverts, road crossing, railroad overpass , railroad overpass, intersections overhead electrical lines, deposit demolition ) (Fig. 1, Tab. 1).

From the field and laboratory analysis, we identified several critical areas between Ploiesti and Buzau in terms of geomorphology, which can be overcome through arrangements for the protection and defense. These critical areas should be identified and reported from initial feasibility study and technical project in order to establishment of adequate alternative and the measures necessary for subsequent operation [1].

TABLE I. STRUCTURES IDENTIFICATION

\begin{tabular}{|c|c|}
\hline Length $(\mathrm{km})$ & 75.80 \\
\hline Number of road junctions & 6 \\
\hline Number of bridges & 6 \\
\hline Total length bridges & $\mathrm{n} / \mathrm{a}$ \\
\hline Number of culverts & 33 \\
\hline Total length culverts & $\mathrm{n} / \mathrm{a}$ \\
\hline Road crossing & 12 \\
\hline Railroad overpass & 4 \\
\hline $\begin{array}{c}\text { Intersections overhead } \\
\text { electrical lines }\end{array}$ & 18 \\
\hline Deposit demolition & 1 \\
\hline Administrative units & $\begin{array}{c}\text { Dumbrava, Albești - Paleologu, Tomșani, } \\
\text { Colceag, Baba Ana, Mizil, Sahateni, } \\
\text { Breaza, Pietroasele, Ulmeni, Merei, Stâlpu, } \\
\text { Buzău, Vadu Pasii, Poșta Câlnău }\end{array}$ \\
\hline
\end{tabular}

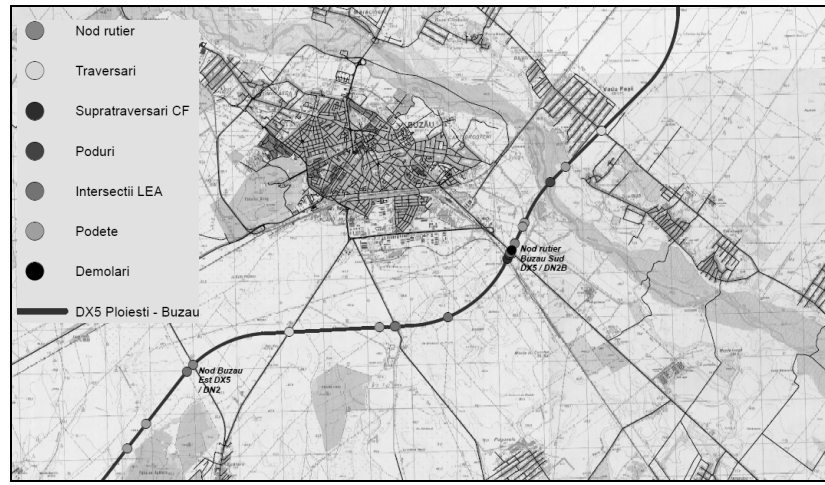

Fig. 1. The identification of the main general geomorphological processes that affect the TEN-T Core and Comprehensive network

The geomorphotechnique analysis aims to harmonize the relation between the geomorphological processes, the construction solutions and the transport infrastructure [2].

The geomorphological approach involves several stages:

- identifying areas along the existing or planned transport networks, which are affected or can be affected by the geomorphological processes;

- establishing the intensity and the maximum manifestation of the geomorphological processes; 
- determining the necessary protection work types in order to protect the transportation infrastructure;

- determining the manifestation area dimension and the solution adopted in correlation with the geomorphological processes intensity.

\section{THE RESULTS}

In this analysis we obtained the best location of the parameters such as: road junctions, bridges, culverts, road crossing, railroad overpass, railroad overpass, and intersections with areal electrical lines, deposit demolition, for the fast road Ploiești - Buzău. We consider that is necessary to use the same approach for the next sectors: Buzău - Focșani, Focşani - Bacău and Bacău Pașcani, for better and faster project implementation.

Generally a straight path is chosen only when using some smart solutions. In many cases we are used large curves succession for using the advantage that the relief provides. These dimensions determine a maximum design speed of $140 \mathrm{~km} / \mathrm{h}$.

From the of 65 km length of Ploiești - Buzău sector, we determined the lengths of the structures pesented in Table II.

TABLE II. THE PARAMETERS PROPOSED FOR PLOIEȘTI - BUZĂU SECTOR

\begin{tabular}{|c|c|c|c|}
\hline Id & $\begin{array}{c}\text { Code } \\
\text { emplacement }\end{array}$ & Characteristic & Validated \\
\hline & \multicolumn{3}{|c|}{ Road junctions } \\
\hline 1 & 1 & Speed road junction A3 / DX5 Dumbrava & Yes \\
\hline 1 & 11 & Cricov node DX5 / DN1D & Yes \\
\hline 1 & 28 & Mizil node DX5 / DJ102H & Yes \\
\hline 1 & 61 & Buzau Est node DX5 / DN2 & Yes \\
\hline 1 & 72 & Buzau Sud node DX5 / DN2B & Yes \\
\hline \multirow[t]{2}{*}{1} & 79 & Buzau Vest node DX5 / DJ220 & Yes \\
\hline & \multicolumn{3}{|c|}{ Overpass and undercrossings } \\
\hline 2 & 2 & DX5 crossing over DJ101F & Yes \\
\hline 2 & 15 & DX5 is crossed over by DJ102N & Yes \\
\hline 2 & 19 & DX5 is crossed over by DJ101E & Yes \\
\hline 2 & 23 & DX5 is crossed over by DJ102D & Yes \\
\hline 2 & 25 & DX5 is crossed over by DC77 & Yes \\
\hline 2 & 39 & DX5 is crossed over by DJ103R & Yes \\
\hline 2 & 46 & DX5 is crossed over by DJ203C & Yes \\
\hline 2 & 55 & DX5 is crossed over by DJ203G & Yes \\
\hline 2 & 62 & DX5 is crossed over by DN2B & Yes \\
\hline 2 & 65 & DX5 is crossed over by DJ203D & Yes \\
\hline 2 & 69 & DX5 is crossed over by DN2B & Yes \\
\hline \multirow[t]{2}{*}{2} & 77 & DX5 is crossed over by DJ203K & Yes \\
\hline & \multicolumn{3}{|c|}{ Railway overpass } \\
\hline 3 & 4 & $\begin{array}{l}\text { DX5 is crossing over the non-electrified } \\
\text { double railway Ploiesti - Urziceni, } 701 \\
\text { route, in operation }\end{array}$ & Yes \\
\hline 3 & 67 & $\begin{array}{l}\text { DX5 over crossing electrified double } \\
\text { railway Buzau - Faurei 702, in operation }\end{array}$ & Yes \\
\hline 3 & 68 & $\begin{array}{l}\text { DX5 crosses over the rail joint Buzau } \\
\text { Sud - Ram. Bobocu } 702 \text { / 500, in } \\
\text { operation }\end{array}$ & Yes \\
\hline \multirow[t]{2}{*}{3} & 78 & $\begin{array}{l}\text { DX5 ver crossing electrified double } \\
\text { railway Buzau - Focsani 500, in } \\
\text { operation } \\
\end{array}$ & Yes \\
\hline & \multicolumn{3}{|c|}{ Bridges over the network basin } \\
\hline 4 & 6 & Bridge over the river Vatmanu & Yes \\
\hline 4 & 10 & Bridge Cricovu Sarat & Yes \\
\hline 4 & 13 & bridgeValea Razboiului & Yes \\
\hline 4 & 36 & Bridge over the river Naianca & Yes \\
\hline 4 & 45 & Bridge over the river Sarata & Yes \\
\hline \multirow[t]{2}{*}{4} & 75 & Bridge over the river Buzau & Yes \\
\hline & \multicolumn{3}{|c|}{ Intersections with aerial electrical lines } \\
\hline 5 & 40 & $\begin{array}{c}\text { LEA } 20 \text { kw between Istrita de Jos and } \\
\text { Gageni }\end{array}$ & Yes \\
\hline
\end{tabular}

\begin{tabular}{|c|c|c|c|}
\hline 5 & 64 & LEA 20 kw between Buzau si Pogoanele & Yes \\
\hline 5 & 3 & $\begin{array}{c}\text { LEA } 20 \text { kw between Dumbrava and } \\
\text { Ciupelnita }\end{array}$ & Yes \\
\hline 5 & 5 & $\begin{array}{c}\text { LEA } 20 \text { kw between Dumbrava and } \\
\text { Trestienii de Jos }\end{array}$ & $\begin{array}{l}\text { To validate } \\
\text { in the field }\end{array}$ \\
\hline 5 & 7 & $\begin{array}{c}\text { LEA } 110 \text { kw between Brazi and } \\
\text { Bucuresti Sud }\end{array}$ & Yes \\
\hline 5 & 14 & LEA $20 \mathrm{kw}$ between Colceag and Perepa & Yes \\
\hline 5 & 20 & $\begin{array}{c}\text { LEA } 20 \text { kw between Baba Ana and } \\
\text { Fulga de Sus }\end{array}$ & Yes \\
\hline 5 & 24 & $\begin{array}{l}\text { LEA } 20 \text { kw between Baba Ana and } \\
\text { Gradistea }\end{array}$ & Yes \\
\hline 5 & 26 & $\begin{array}{c}\text { LEA } 20 \text { kw between Baba Ana and } \\
\text { Ciresanu }\end{array}$ & Yes \\
\hline 5 & 27 & $\begin{array}{l}\text { LEA } 20 \text { kw between Baba Ana and } \\
\text { Ciresanu }\end{array}$ & $\begin{array}{l}\text { To validate } \\
\text { in the field }\end{array}$ \\
\hline 5 & 33 & LEA 400 kw between Brazi and Stalpu & Yes \\
\hline 5 & 37 & LEA 20 kw Sahateni - Gageni & $\begin{array}{l}\text { To validate } \\
\text { in the field }\end{array}$ \\
\hline 5 & 41 & LEA 400 kw between Brazi and Stalpu & Yes \\
\hline 5 & 54 & $\begin{array}{c}\text { LEA } 110 \text { kw between Stalpu and } \\
\text { Pietrosu }\end{array}$ & Yes \\
\hline 5 & 56 & LEA $20 \mathrm{kw}$ between Stalpu and Pietrosu & Yes \\
\hline 5 & 60 & LEA 20 kw between Buzau and Spataru & Yes \\
\hline 5 & 66 & AE L $110 \mathrm{kw}$ & Yes \\
\hline \multirow[t]{2}{*}{5} & 70 & AE L $20 \mathrm{kw}$ & Yes \\
\hline & \multicolumn{3}{|c|}{ Culverts } \\
\hline 6 & 8 & Culvert over wet area, the torrent origin & Yes \\
\hline 6 & 9 & Torrent culvert Valea Mare & Yes \\
\hline 6 & 12 & $\begin{array}{c}\text { Torrent culvert tributary Valea } \\
\text { Razboiului vest }\end{array}$ & Yes \\
\hline 6 & 14 & $\begin{array}{c}\text { Torrent culvert tributary Valea } \\
\text { Razboiului est }\end{array}$ & Yes \\
\hline 6 & 16 & Culvert over Viroaga Ceptura & Yes \\
\hline 6 & 17 & Culvert over Paraul Balana & Yes \\
\hline 6 & 18 & Culvert over Valea Baba Sima & Yes \\
\hline 6 & 21 & Culvert over irrigation channel & Yes \\
\hline 6 & 22 & Culvert over Paraul Ghighiu & Yes \\
\hline 6 & 29 & $\begin{array}{l}\text { Culvert over irrigation channel and } \\
\text { agricultural road }\end{array}$ & Yes \\
\hline 6 & 30 & $\begin{array}{c}\text { Culvert over irrigation channel and } \\
\text { agricultural road }\end{array}$ & Yes \\
\hline 6 & 31 & $\begin{array}{l}\text { Culvert over irrigation channel and } \\
\text { agricultural road }\end{array}$ & Yes \\
\hline 6 & 32 & $\begin{array}{l}\text { Culvert over irrigation channel and } \\
\text { agricultural road }\end{array}$ & Yes \\
\hline 6 & 34 & $\begin{array}{l}\text { Culvert over irrigation channel and } \\
\text { agricultural road }\end{array}$ & Yes \\
\hline 6 & 35 & $\begin{array}{c}\text { Culvert over irrigation channel and } \\
\text { agricultural road }\end{array}$ & Yes \\
\hline 6 & 38 & $\begin{array}{c}\text { Culvert over irrigation channel and } \\
\text { agricultural road }\end{array}$ & Yes \\
\hline 6 & 42 & $\begin{array}{c}\text { Culvert over irrigation channel and } \\
\text { agricultural road }\end{array}$ & Yes \\
\hline 6 & 43 & $\begin{array}{c}\text { Culvert over irrigation channel and } \\
\text { agricultural road }\end{array}$ & Yes \\
\hline 6 & 44 & $\begin{array}{c}\text { Culvert over irrigation channel and } \\
\text { agricultural road }\end{array}$ & Yes \\
\hline 6 & 47 & $\begin{array}{l}\text { Culvert over irrigation channel and } \\
\text { agricultural road }\end{array}$ & Yes \\
\hline 6 & 48 & $\begin{array}{l}\text { Culvert over irrigation channel and } \\
\text { agricultural road }\end{array}$ & Yes \\
\hline 6 & 49 & $\begin{array}{l}\text { Culvert over irrigation channel and } \\
\text { agricultural road }\end{array}$ & Yes \\
\hline 6 & 50 & $\begin{array}{c}\text { Culvert over irrigation channel and } \\
\text { agricultural road }\end{array}$ & Yes \\
\hline 6 & 51 & Culvert over agricultural road & Yes \\
\hline 6 & 52 & $\begin{array}{c}\text { Culvert over irrigation channel and } \\
\text { agricultural road }\end{array}$ & Yes \\
\hline 6 & 53 & $\begin{array}{l}\text { Culvert over irrigation channel and } \\
\text { agricultural road }\end{array}$ & Yes \\
\hline 6 & 57 & $\begin{array}{c}\text { Culvert over irrigation channel and } \\
\text { agricultural road }\end{array}$ & Yes \\
\hline 6 & 58 & Culvert over Paraul Calmatui & Yes \\
\hline 6 & 59 & Culvert over Paraul Calmatui & Yes \\
\hline 6 & 63 & $\begin{array}{c}\text { Culvert over torrent Stramba Maneasca } \\
\text { Est }\end{array}$ & Yes \\
\hline 6 & 73 & $\begin{array}{c}\text { Culvert over irrigation channel and } \\
\text { agricultural road }\end{array}$ & Yes \\
\hline 6 & 74 & $\begin{array}{c}\text { Culvert over irrigation channel and } \\
\text { agricultural road }\end{array}$ & Yes \\
\hline 6 & 76 & Culvert over Buzau river arm & To valid \\
\hline
\end{tabular}




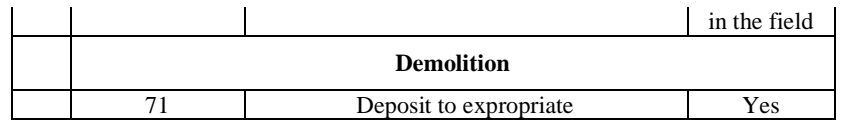

\section{CONCLUSIONS}

The GIS provided solutions were subsequently validated based on the performed work in the field. This analysis demonstrated that this type of study is a good point for infrastructure road project starting.

We consider therefore that the geomorphotechnique analysis is an important step from the major project implementation. The geomorphotechnique map can be considered a very useful tool for both designers and engineers.

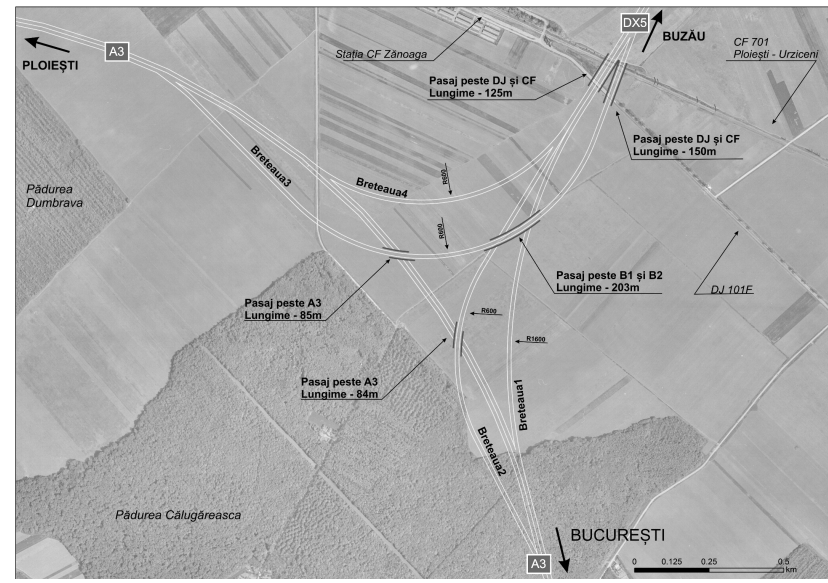

Fig. 2. The location node Dumbrava road speed $(\mathrm{km} .52+150 / 0+000)$ wide. $44^{\circ} 50^{\prime} 51.61$ "N, long. $26^{\circ} 12 ' 23.82 "$

\section{REFERENCES}

[1] R. Dobre, "Relaţia dinamica reliefului-infrastructura de transport", Editura Etnologică, București, 2016. (in Romanian)

[2] R. Dobre, "Pretabilitatea reliefului pentru căi de comunicații şi transporturi în Culoarul Prahovei (sectoarele montan şi subcarpatic)", Editura Universitară, Bucureşti, ISBN 978-606-591235-9, 245 p, 2011. (in Romanian) 